Trivent Publishing

(C) The Authors, 2018

Available online at http:/ / trivent-publishing.eu/

Series: Applied Ethics: From Bioethics to Environmental Ethics

\title{
(Bio)ethical Education for Young People in Macedonia
}

\author{
Dejan Donev \\ Institute of philosophy, Faculty of philosophy, \\ University "St. Cyril and Methodius," Skopje, R. of Macedonia
}

\begin{abstract}
Since 1998, a campaign has been going on for including ethical and bioethical education in Macedonia. After years of struggle with the Ministry and the Bureau of Education, this process is finally completed. Bioethical education was introduced as part of ethical education, as a practical pedagogical activity in different schools and on different educational levels - from kindergarten to master and doctoral studies. Furthermore, the method used for the ethical-bioethical education of young people proved to be very interactive and, at the same time, it discovered the route for the contemporary ethical education of the youngest children.
\end{abstract}

Keywords: ethical education; bioethical themes; young people; practical pedagogical activity; educational system.

This is an Open Access article distributed in accordance with the Creative Commons Attribution Non Commercial (CC-BY-NC-ND 4.0) license, which permits others to copy or share the article, provided original work is properly cited and that this is not done for commercial purposes. Users may not remix, transform, or build upon the material and may not distribute the modified material (bttp:/ / creativecommons.org/licenses/by-nc/4.0/) 


\title{
(Bio)ethical Education for Young People in Macedonia
}

\author{
Dejan Donev
}

\section{Introduction}

Today, bioethics is an important and complex field of thinking and activity. Although a young science, it is among the most important visions and concerns that humanity is facing. Every day new questions enter the scope of bioethical thinking -- issues and discussions above all. Meanwhile, many efforts are invested into debates whether bioethics should be primarily limited to the medical sphere (medicine, veterinary medicine, nursing, pharmacy, biological investigations on treating human lives) or whether it bioethics should be treated as a broader, large discipline, like modern practical ethics, in general. These questions, which result in scientific arguments, cannot be solved empirically - each one stands still in this debate for the moment! This is why good faith and collaboration among experts who have the duty to promote bioethics and its benefits are more than needed.

At the same time, knowing this, bioethical education cannot be postponed until the definite settlement of the scientific debate on the scientific purity of bioethics or the specific status of bioethics as a specialized or general science and practice (thus, whether the nature of bioethics is primarily biological or ethical). Many issues are strongly knocking on our doors: health problems, environmental pollution, violence and conflicts, human indolence, criminal deeds as well as negative behaviours of different kind. All these problems require serious and fast human action. This is why it is so important to introduce bioethical education to everyone.

In reality, the bioethical practice and science started at the same time as the development of ethical education, which included all young people (as well as older, if possible). It is so because the complex subject of bioethics matters not only to scientists and specialists, but they also concern every human being - all living as well as non-living beings on Earth. Therefore, everyone must be educated with regard to this new and elaborate area which is both spiritual and technical in nature. Furthermore, besides the numerous philosophical, social, 
and pedagogical issues it raises, the most important aspects in every educational system relate to the content and method of teaching. The aspect of content is a more interesting question for bioethical education as it is a new kind of education whose topics and arguments constructuct bioethics as a new science. It is therefore a field people are currently acting upon.

\section{The development of the idea and practice of ethical and bioethical education in Macedonia}

Starting with 1998, a campaign has been conducted for including ethical and bioethical education in the curriculum in the Republic of Macedonia. For at least 12 years, Prof. Kiril Temkov has been publishing in major journals and other media an open call to the Ministry of Education to persuade them to include first of all ethics and then bioethics as subjects matters on all levels of education -- or at least to permit the realization of the experimental ethical and bioethical education [1].

After years of struggle with the Ministry and the Bureau of Education, the process was accomplished, not only with the explanation of the meaning of these sciences, the essential need for them, the necessity of educating the young in these areas, the content of this kind of education, but also with the practical pedagogical activity in different schools at different educational levels - from kindergarten to master studies where bioethical education was mainly introduced as part of ethical education.

Extensive experimental teaching (courses) of ethics was introduced in high schools as well as in primary education and in kindergartens. Also, at the beginning of the 1990s, chapters on bioethics were introduced in the studies of Ethics and the History of Ethics for future philosophy teachers as well as in the education of other students from different faculties.

\section{Experimental teaching in high schools and faculties}

In 1998, there was an action of introducing ethics on all levels of education. The initiator of the process, Prof. Kiril Temkov, developed a program for experimental ethical and bioethical education in Macedonian high schools in four towns. The educational goals were to explore the possibilities of understanding and communication by young generations between ages 15 and 19 on ethical-bioethical problems and values. In two of them (specialized biotechnical schools), in the Agriculture-Veterinary High School in Drachevo, Skopje and in the Agriculture-Forestry School in Kavadarci, teachers Marija Taseva and dr. Jovan Lozanovski taught bioethics for the first time on high school level.

All questions of ethical education in these two schools had bioethical perspectives - understanding the position of human beings in the world and 
the proposed bioethical value system and moral norms. The program was composed of special lectures, such as lectures on the notion of bioethics, the history of bioethics, especially the ideas of bioethics, the system of human thinking, the evaluation and activity under bioethical dimensions, etc. This pedagogical experiment had a sense of bioethical education with general orientation as well as with contents of lessons, examples, and knowledge.

The high school in Drachevo founded a centre for researches in ethical and bioethical education for the youth, with the purpose of becoming an institute for this kind of education. However, the political changing of the school principals and the unfortunate discharge of useful spiritual and educative initiatives brought about a lack of continuity in the centre - initially, a special four-year programme for continuous bioethical education for high school pupils was established, but unfortunately, only a two-year course with one group was realized. The chance to implement bioethical education in high schools as well as use the extended experience in this field of science on other levels of education was stopped. At the same time, the organization of an experimental ethical teaching programme in the biggest biotechnical high school in Skopje was stopped by the Ministry of Education. Therefore, all the experience we had was reduced to only two years of education.

However, the former school principal, Jovan Lozanovski finished his dissertation on the methods of ethical education, as the first $\mathrm{PhD}$ on this matter in Macedonia. The results of the dissertation were published in Prof. Kiril Temkov's book Good, Better, The Best (Ethics and Youth) [2], where methods of ethical-bioethical education in high schools were explained and also the educational programmes for this kind of experimental education were analyzed, which later on became a groundwork for the programmes for ethical education in the $\mathrm{II}^{\text {nd }}$ and in $\mathrm{III} \mathrm{I}^{\mathrm{rd}}$ classes $\left(10^{\text {th }}\right.$ and $11^{\text {th }}$ grades $)$ in Gymnasiums in Macedonia.

On the level of higher education, all the activity done for launching the teaching of ethics in Macedonia was most important contribution in the process of propagating the idea for bioethics. First of all, in the education of teachers of philosophy there was an introduction on bioethical questions in their study of ethics and the history of ethics and then a special course on ecological ethics in graduate studies. A few years ago, another elective subject was given at the Faculty of Philosophy ("St.s Cyril and Methodius" University in Skopje) under the name "Foundations of Bioethics" [3]. Also, it was proposed that bioethics be introduced as a special subject in the master studies in Philosophy, an idea which was finally realized in 2012 [4], when I pushed the programme of bioethics through the Faculty of Law - a programme that was (and still is) an elective course for all students of this faculty's master programme. 
Meanwhile, in 1998, the Faculty of Philosophy ("St.s Cyril and Methodius" University in Skopje) sent Prof. Temkov's letter to all faculties of the same university in a plea for the necessity of ethical education and for promoting bioethical research and courses, as well as for developing ethics in science). A few years later, it was proposed that the Faculty of Agriculture and Forestry introduced bioethics as subject of their basic studies, but the proposal was never followed through. At the same time, while bioethics became the main content of the new programmes in ethics, it was introduced [5] for students of Psychology, Pedagogy, Journalism, Arts, and other sciences.

In this context, one of the main aims of this struggle was to introduce bioethics in scientific development as graduate or postgraduate subjects in all fields, as part of the ethics of science (which should be obligatory in every kind of graduate or postgraduate studies). This project was presented at a round table discussion concerning this matter at the St. Cyril and Methodius University in Skopje in June 2007 (the resulting materials were edited under the title Ethics in contemporary science) [6]. Since then, bioethics represents $30 \%$ of the core content of the obligatory course titled "The ethics of scientific research" in doctoral schools [7].

\section{Experimental teaching in primary schools and kindergartens}

This entire process started with the idea that all children should study ethics and bioethics. The process was accomplished in 2000 with the experimental ethical education in sixth grade classes, where 12 year old children learned the basics of ethical knowledge, the most relevant moral values, as well as the special questions and norms of bioethics. This was the subject of the master thesis written by Ilinka Torbovska-Smilevska [8]. The lessons and texts used during this process were the well-known children reviews "Kolibri," published weekly in the oldest Macedonian newspaper "Nova Makedonija" between 2000 and 2002 (part of these texts were translated into Bulgarian and used in civic education in Bulgaria). A book with all this material was published under the title Love and Care (Ethics for the Youngest) [9], which discussed basic ethical and bioethical values of our time.

Further on, the most important experiment carried out was done in the second and third grades in the primary school of "Vlado Tasevski" in Skopje in the academic years of 2003/2004 and 2004/2005. The classes were taughts by Ljubica Topuzoska, graduated pedagogue, with an MA degree in philosophy. The two-year experiment conducted in her class represented a solid base for the master thesis titled Ethical education in class teaching [10] in 2004 and the doctoral dissertation titled "Forms and methods of ethical education in class teaching" [11] in 2006. 
In teaching the second graders, the method of Example and Edification was primarily used. Over 80 ethical stories were created - all of them regularly published every Tuesday in the "Kolibri" reviews of "Nova Makedonia" (2003-2004); this way, the materials were available for reading and discussion to a large number of children in many schools. In the second semester, the content of ethical education was divided into six areas, two of them entirely bioethical - Health and Environmental care. Several years later, in 2007, these texts were published in a book titled Ethics for Children [12]. Also, the Ecological lexicon [13] was also used as additional material in teaching.

Third graders learned ethics in two forms - in the first semester the stress was on Dilemmas and making a Choice, while in the second one, Moral Evaluation was put in discussion. 20 special texts presented ethical and bioethical situation in which the heroes were children. The children were then requested to explain what they would do in particular cases. The bioethical themes from these stories were concerned with personal hygiene, the relationship with violent children, the problem of noise and powder rockets on New Year's Eve, etc. Later on, in the next semester, children were asked to give an ethical evaluation of somebody's behaviour. Here, bioethical themes were chosen from different forms of children's cultural and social behaviour (dance, help, etc.), as well as questions of the first love, of the relationship between brothers and sisters, meeting the strange world, etc. The children particularly enjoyed two of the texts. They were related to the problem of plant well-beingand the question of keeping pets and flowers received as gifts, as well as the responsibility one has for them as living beings.

In that time, bioethical content was represented in only one particular ethical-pedagogical material: the first ethical comic in Macedonia titled Angela and Angel from the $1^{\text {st }}$ A grade. In the academic year 2004/2005, 19 comics were created and another 19 in 2005/2006 with interactive reading materials. The idea was to bring bioethical themes closer to children. In fact, the aim of the comic was to present the life of two neighbourhood friends who are going in school together in $1^{\text {st }}$ grade. Most of the texts dealt with bioethical topics: personal, home, and school hygiene; regular nutrition; nonviolent relations between children; children's games in nature; the weather and the seasons; meeting and loving animals; comparing lifestyles in different environments (urban versus rural), etc.

Furthermore, the process had to be introduced to kindergarten, as well.. Between 2003 and 2005, 4 kindergartens in Skopje introduced ethical education on matters of Love, non-violence, peace, help and good behaviour. This involved the usage of many stories, designs, shows for children, education for teachers and parents, etc. A special game was prepared with eco-bioethical content on recognizing the home of animals, on plants and their fruits, on the 
ways they should be kept, on expressions of love for natural creatures, the child's behaviour towards nature, etc.. This process was recorded and a television documentary was produced on its information. The documents and ideas of the process were later published in the book titled Ethics and Love [14]. Because of this entire activity, some kindergartens today employ special Ecological education as part of their bioethical (human) upbringing.

\section{Additional forms of spreading ethical and bioethical education for young people}

Since the first experimental courses on ethics and bioethics were developed, numerous materials were published and disseminated. The materials of Prof. Temkov on experimental teaching are most noteworthy, but so are the numerous other publications: monographies, proceedings, articles, etc.

A series of lessons were published in a weekly newspaper as the first bioethical texts and lessons in Macedonia with the purpose of experimental ethical-bioethical education. Later, the series was a basis for the book Good, Better, The Best (Ethics and Youth), the first edited book in large format published as private edition, translated into Serbian and after that edited in Macedonia in the same form [15]. In this book, Prof. Temkov published lessons on bioethics, ecological ethics, ethics of health and ethics of addictions which were used in the experimental teaching of Ethics in primary school - in the $6^{\text {th }}$ (2000) and $2^{\text {nd }}$ grades (2003/2004), while also providing value-related education for children aged 5-6 in kindergarten (2004).

There are also the books titled Love and Care (Ethics for the Youngest) and Ethics for Children, which discuss the definition of bioethics, the survey of development, the fields and values of bioethics, the moral norms in bioethics, and the future tendencies in bioethics.

In his book Ethics today [16], Temkov dedicated special parts to "Bioethics" and to "Addictions and Drugs" and he revealed how the status of ethics has changed - from the ethics of virtue to the ethics of nature. The book introduced and discussed the topics of bioethics, ecological ethics, health ethics, ethical aspects of infectious diseases and the ethics of addictions (especially of drugs). The book highlighted that today's the most important bioethical dimensions are the ones concerning the moral aspects of personal, social, domestic, economic and political ethics as values and tasks.

Other publications discussed similar topics, such as Ethical Dictionary For The Youth [17], The Ecological Basic Textbook [18], and many more, as well as new high school textbooks on ethical education: Ethics for the $2^{\text {nd }}$ grade [19] and "Ethics for the $3^{\text {rd }}$ grade" [20]. All these books for young people present bioethics as the most significant ethical problem of today. This is a new perspective, as bioethics mainly concentrates on specialized activities and the education of 
specialists for particular professions (medicine, biology, etc.), and it is "not part of wide base on comprehensive education with a mission to build a wide bioethical consciousness in everybody" [21, pp. 152-170].

The series "Ethicists" was first published in the newspaper "Start" (20032004) and later as a book titled "Ethicists - the 100 most important philosophers of moral: From Zarathustra to Bioethics" [22]. It presented the bioethical ideas of the most important ethical thinkers such as Albert Schweitzer, Pavao Vuk-Pavlovic, Rachelle Carson, Peter Singer, and others, from the first ethicists to the most modern ones.

In 2004, the Ethical Centre was founded in Skopje. The Centre's first seminar for students was dedicated to the problem of drugs, followed by other discussions of relevant bioethical issues.

The legacy of MA theses is also important: Ethical education in class teaching by Ljubica Topuzovska, Ethical education in high schools in Macedonia by Jovan Lozanovski [23], Ethics as a subject in primary schools by Ilinka TorbovskaSmilevska, to mention just a few. Doctoral dissertations should also be meantioned, such as Forms and methods of ethical education in class teaching by Ljubica Topuzoska, Forms, methods and means in teaching ethics in high schools by Jovan Lozanovski [24], which present the urgent need and forms of bioethical education as a part of the ethical education.

Finally, following the achievement of this level of discussions on bioethics education, besides the efforts of Prof. Temkov and his associates for opening the path for bioethics in the academic world in Macedonia, there is also the realization of the thematic block Bioetbics: Occurrence, Challenges and Opportunities [25], edited by Dejan Donev in the scientific journal Philosophy from 2011 onwards. In addition, there the Proceedings of the first international interdisciplinary conference "Bioethics - The Sign of a New Era: Bioethics, Media, Law and Medicine" [26], that Donev organized with the Faculty of Law "Justinijan I" of the "St.s Cyril and Methodius" University in Skopje and the Centre for Integrative Bioethics from Kumanovo, in 2011, in Ohrid, Macedonia. Therefore, the ground was prepared for further actions of integrating Bioethics in the educational system of Macedonia.

\section{Conclusion}

The context of ethical education of young people in Macedonia is often dedicated to bioethical themes and problems. Young people learn bioethical questions very easily, especially children, who enjoy stories about animals and plants, and are interested in the bioethical side of existence. Hence, bioethical themes are best for introducing the study of ethics, as they also ennoble the ethical conscience with the idea of a good relationship with nature and other 
living beings. For instance, the experimental ethical teaching in the $2^{\text {nd }}$ and $3^{\text {rd }}$ grades in Skopje showed that bioethical content is unavoidable in the formation of a young person who will live in a new world of understanding, in good human relationships and proper behaviour towards nature. This experimental teaching programme showed that the children were very interested in bioethical issues and the bioethical themes easily found a path to their hearts.These researches used and analyzed the methods of ethicalbioethical education through edification, dilemma-choice and evaluation, as the best three methods of ethical education for young people. Furthermore, the method used for the ethical-bioethical education of young people was proven to be highly interactive and, at the same time, it discovered the "recipe" for the contemporary ethical education of the youngest children.

To conclude, the manifestation and theory of bioethics and is just as important as practical ethics. In the future, ethics might become bioethics, because the meaning of the biological factors of living are highyimportant (life, nature, the human being, as basic categories of bioethics), especially in era time when they are violated from various sides, including people's own negative behaviour. That is why we should engage in ethical education as a new kind of ethical-pedagogical activity. This is the type of education that should be implemented on all levels of education, so that society can understand and implement the new aspects of human living which are expressed through the reality of Bioethics.

\section{References}

[1] Shortage of mercy for our young ("Недостиг на мимост за нашите млади"). http:/ / star.vest.com.mk/default.asp?id=89470\&idg $=5 \& \mathrm{idb}=1358 \&$ rubrika $=$ Po\%7Bta. Accessed: July 16, 2017.

[2] K. Temkov. Good, Better, The Best (Ethics for youth) (Dobro, bolje, najbolje - Etika za mlade). Niš: Samizdat, 2003.

[3] Study program - philosophy ("Студиска програма - филозофија"). http://www.fzf.ukim.edu.mk/ddtest21/public/uploads/files/00programin ovi/Prilog_br_4_studiska_rograma_-_filozofija.pdf. Accessed: July 16, 2017.

[4] http://ukim.edu.mk/mk_content.php?meni=163\&glavno=40. Accessed: July 16, 2017.

[5] "List of subjects of the Faculty of Philosophy” („,иста на предмети оА Филозофски факултет"). http://www.ukim.edu.mk/dokumenti_m/312_Filzoofski_lista$\% \mathrm{D} 0 \% \mathrm{BD} \% \mathrm{D} 0 \% \mathrm{~B} 0$ $\% \mathrm{D} 1 \% 98 \% \mathrm{D} 0 \% \mathrm{BD} \% \mathrm{D} 0 \% \mathrm{BE} \% \mathrm{D} 0 \% \mathrm{~B} 2 \% \mathrm{D} 0 \% \mathrm{~B} 0 \_$web.pdf. Accessed: July 16, 2017. 
[6] K. Temkov. Ethics in contemporary science. Skopje: UKIM, 2007.

[7] "List of proposed subjects” („Аиста на предложени предмети“). http://www.ukim.edu.mk/dokumenti_m/262_Lista_na_predloznei_pred meti_genericki_znaenja.pdf. Accessed: July 16, 2017.

[8] I. Torbovska-Smilevska. Ethics as a subject in prime schools ("тиката како предмет во основните училишта). MA thesis, Dept. of Philosophy, St. Cyril and Methodius University. Skopje, 2001.

[9] K. Temkov. Love and Care (Ethics for the Youngest) (bубов и Грижа - Emика за нajuлadume). Skopje: Samizdat, 2002.

[10] Lj. Topuzovska. Ethical education in class teaching (Етичкото образование во одлеленската настава). MA thesis, Dept. of Philosophy, St. Cyril and Methodius University. Skopje, 2004.

[11] Lj. Topuzovska. Forms and methods of ethical education in class teaching (Видови и методи на етичкото образование во одцеленската настава). $\mathrm{PhD}$ dissertation, Dept. of Philosophy, St. Cyril and Methodius University. Skopje, 2006.

[12] K. Temkov. Etbics for Children (Eтика за deua). Skopje: Samizdat, 2007.

[13] K. Temkov. Ecological lexicon (Еколоики лексикон). Skopje: Samizdat, 2003.

[14] K. Temkov. Ethics and Love (Eтика и вубов). Skopje: Samizdat, 2007.

[15] K. Temkov. How to be a good (Ethics for youth) (Како da ce биде добар - Emика за млаdu). Skopje: OHO, 2007.

[16] K. Temkov, Ethics today, (Eтиката денеc),Skopje: Epoha, 1999.

[17] K. Temkov, Ethical dictionary for Youth, (Етички речник за млади), Skopje: Epoha, 2001.

[18] K. Temkov. Ecological basic textbook (Еколошки азбучник). Skopje: Samizdat, 2003.

[19] K. Temkov. Ethics for II class (Eтика за II клас). Skopje: Prosvetno delo, 2004.

[20] K. Temkov. Ethics for III class (Eтика за III клac). Skopje: Prosvetno delo, 2004.

[21] K. Temkov. Ethics (Emикa). Skopje: Epoha, pp. 152-170, 1998.

[22] K. Temkov. Ethicians - 100 most important philosophers of moral: From Zarathustra to Bioethics (Етичари - 100 највлијателни филозофи на моралот: од Заратустра до Биоетиката) http://www.arh.ukim.edu.mk/images/IzborniPredmeti/Estetika/ETICA RI-PRV_DEL.pdf. Accessed: July 16, 2017.

[23] J. Lozanovski. Ethical education in high schools in Macedonia („Етичкото образование во средните училишта во Македонија“). MA thesis, Dept. of Philosophy, St. Cyril and Methodius University. Skopje, 1999. 
(Bio)ethical Education for Young People in Macedonia

[24] J. Lozanovski. Forms, methods and means in teaching ethics in high schools (Формите на работа, методите и средствата на наставата по етика во средните училишта). PhD dissertation, Dept. of Philosophy, St. Cyril and Methodius University. Skopje, 2001.

[25] D. Donev (ed.). "Bioethics: Occurrence, Challenges and Opportunities." Philosophy 31 (2011).

[26] D. Donev (ed.). "Bioethics - The sign of a new era: Bioethics, media, law and medicine.” In Proc. First International interdisciplinary conf., Skopje, 2012. 